\title{
Ethnic Dilemma in Pakistan and Division of Punjab: End or Beginning of the New Era of Conflict
}

\author{
Yasmin Roofi $^{1}$ \& Khawaja Alqama ${ }^{2}$ \\ ${ }^{1}$ Department of Political Science, The Islamia University of Bahawalpur, Pakistan \\ ${ }^{2}$ Vice Chancellor, B. Z. University Multan, Pakistan \\ Correspondence: Yasmin Roofi, Department of Political Science, The Islamia University of Bahawalpur, \\ Pakistan. Tel: 92-062-925-5461. E-mail: Yasminroofi22206@yahoo.com
}

Received: October 27, 2012 Accepted: November 5, 2012 Online Published: February 26, 2013

doi:10.5539/jpl.v6n1p156

URL: http://dx.doi.org/10.5539/jpl.v6n1p156

\begin{abstract}
Punjab is the largest province in Pakistan in terms of population and enjoys a vital position in politics. The dominant role of Punjab has been under criticism in the political history in the past but now it has taken a serious mood. The protagonists of this division claim that province is a multi-lingual and it should be divided on ethnic lines. Even elites from other provinces favor the division to eliminate the powerful position of Punjab but division of Punjab within the given political framework will make the ethnic plurality in Pakistan more problematic and leave an enduring impact on other provinces.
\end{abstract}

Keywords: Punjab, Pakistan, ethnic conflict, Saraiki Nationalism

\section{Introduction}

Pakistan is a multi-lingual, multi- ethnic federation which has been under certain pressures and strains since its inception. Ethnic dilemma has haunted the country throughout her political history. The center province relations have been skewed and federating units particularly smaller ones have been complaining of political and economic marginalization. The multiple reasons of this conflict are pointed out by scholars and politicians but the major allegation has been the dominant role of Punjab in the federation. Though the voices were raised in the past to reconfigure the provincial boundary and draw new provinces out of it but now this demand has taken different turn in present regime of PPPP (Pakistan People's Party Parliamentarian) and majority of the political parties including the ruling one are talking about its division. The protagonists of this demand claim that this division not only, will solve the ethnic dilemma in the province but it would be helpful to strengthen the federation of Pakistan. But keeping in view the intra provincial ethnic character of Punjab and other federating units, the fear is that this division will affect the other provinces and ethnic conflict may aggravate in future.

\section{Punjab in Colonial Period}

Punjab enjoyed the important position in United India during British rule and dominated in all fronts during the two World Wars. Punjab was the last settled region which was annexed by the British. (Note1) This left an important impact on socio-economic character of Punjab. Its 50.6 percent population was Muslim according to Census of 1921. There were 35.7 percent Hindus and 12.1 percent Sikhs in the province. The remaining less than two percent population was comprised of Christians, Parses, Janis and Buddhists etc. The Muslims were in majority in North Western parts of the province but they were mostly inhabitants of rural areas. Only 10 percent Muslim population was settled in urban areas of Punjab (Salamat, 1997, pp.3-4). Ayesha Jalal writes that Punjab being a strategically situated Muslim majority area was important to Central Leadership of Muslim League and its inclusion was indispensable to the creation of a new state and even Muhammad Ali Jinnah acknowledged its importance by calling it the corner stone of Muslim Home Land (Jalal, 1985, p.19). As Ian Talbot says, "if Punjabi Muslims have not supported the Muslim League, Pakistan could never have come in to existence" (Talbot, 1990, p.82). During that period, Punjab was under the rule of Unionist Party which was an alliance of three religious communities; Muslims, Hindus and Sikhs. This party was founded by Mian Fazl-e- Hussain and Chotu Ram. As Punjab was an agrarian region and interests of landed class were well protected by the Unionists so the party had its base in rural Punjab and was dominated by feudals such as Tiwanas, Mumdots and Daultanas (Shah, 1997, p.129). Muslim League was not in a position in Punjab to win without making adjustments with 
Unionists. Dr. Muhammad Waseem writes that the Muslim members of Unionist party were a challenge for Muslim League. Even members of Punjab Muslim League under the leadership of Sir Mohammad Shafi had rifts with Muhammad Ali Jinnah and parted their ways over the issue of Simon Commission. (Note 2) It was another setback for central command of Muslim League because this region was vital for Muslim League demand for Pakistan. Muhammad Ali Jinnah tried to bring the political groupings in Punjab under the banner of Muslim League but he was refused by Mian Fazl-i-Hussain (Waseem, 1994, p. 65). This was very disappointing situation for Muhammad Ali Jinnah so he left Punjab by saying that he would never come back again as it was a hope less place (Hussain, 1966, p.311). But two incidents paved a way of success and Muslim League was finally able to penetrate in Punjabi politics. Ayesha Jalal is of the opinion that the first reason was death of Sir Fazl-i-Hussain in 1936 which removed the last hurdle and Mohammad Ali Jinnah was successful to bring Punjab in to his control (Jalal, 1985, p.84). Sikandar Hayat, the successor of Fazl-i-Hussain signed an agreement with Muhammad Ali Jinnah in 1937 known as Sikandar Jinnah Pact. The objective of signing this Pact was to keep Muslim League's influence out of Punjab but actually it provided an opportunity to Muslim League to penetrate in the province. Another reason which became a cause of Muslim League's success in Punjab was British involvement in Second World War. Punjab was the biggest recruitment center for British Indian Army in United India with the 60 percent strength in army officers and 70 percent in other ranks. This province was directly affected by the World War (Amin, 1988, p.76)because a large number of Punjabi soldiers died during the War and many returned handicapped and even were not allotted agricultural lands in the canal colonies (Shah, 1997, p.131). It created a sense of uneasiness in Punjab and as Unionists were helping the British government so their popularity started to decline which helped Muslim League to make foot hold in the province and finally Mohammad Ali Jinnah was able to have an understanding with Sikandar Hayat and annual session of Muslim League was held in Lahore, Punjab in March, 1940 where historic resolution was passed demanding a separate country for Muslims of Sub-Continent based on two Nations Theory (Note 3). Finally Muslim League was successful to prove its claim to be the solely representative party of Muslims in elections of 1946 while securing 75 seats against the Unionist who captured only13 seats (Waseem, 1994, p. 68). The British Government announced partition plan on $3^{\text {rd }}$ June 1947 and Pakistan came in to existence on $14^{\text {th }}$ of August 1947 comprising of Muslim Majority areas.

\section{Post-independence Punjab}

After partition, Pakistan was declared a federation comprising of four provinces, Balochistan, Princely states and tribal areas. All provinces and federating areas were ethnically diverse but Muslim League's future scheme of decentralized state during independence movement brought them together as they could retain their identity and autonomy under this formula (Note 4).The Government of India Act 1935 became an interim constitution for this newly born state and process of constitution making was started. This was a gigantic task and main issue was provincial representation and division of powers among Central Government and federating units. The first report of Basic Principles Committee (BPC) created furor in East Bengal (Note 5). The Bengalis rejected this report and staged protests against it. Their point of view was that it did not provide due share to them based on their numerical strength. After postponement of this report, the second report was announced on December 22, 1952. According to this report the East Bengal had fifty percent share in the upper house of central legislature while rest of the fifty percent representation was given to the other federating units. This time the reaction in Punjab was extremely unfavorable. The opponents alleged that a single federating unit was given half of the representation in central government which was a violation of federal principle. They demanded representation in the lower house of the Parliament based on population. This report created a sense of uneasiness and deprivation among other provinces and process of constitution making became more problematic. One Unit scheme, an attempt to create parity between two wings of country proved a crushing blow to smaller provinces as Sindh, N.W.F.P. Balochistan area and other princely states were merged in a single federating unit called West Pakistan. Though Punjab was charged by other provinces in this regard but the reality is that Chief Minister of Punjab Feroz Khan Noon was against this scheme (Malik, 1997, p. 206). Despite of all of this, the Central Government did not pay any concern to the demands of the people and grievances were intensified. As Iftikhar H. Malik says that "the official preference for a unitary, centralist state through maintenance of India Act 1935 and One Unit scheme created deep feeling of alienation among smaller provinces"(Ibid). The Constitution of 1956 which was drafted and implemented after nine years declared Pakistan a federation comprising of two provinces. The powers were divided in three categories, central, provincial and concurrent giving central government supremacy on provincial governments. Unfortunately, this constitution did not work more than two and half years and Pakistan had to experience her first Martial Law in 1958. The second constitution was a product of military ruler which had a centralized presidential system giving president absolute veto power. The grievances were even intensified in provinces during centralized military regime. Punjab was again under 
criticism because Punjabis were in majority in Pakistan Army (Note. 6) so Martial Law was viewed as Punjabi dominance by other ethnic communities particularly Bengalis (Cohen 2000, p. 44). There were also grievances by Bengalis against Federal Government regarding economic deprivation and marginalization which resulted in separation of Eastern wing in 1971.

The Constitution of 1973 brought a ray of hope for truncated federation of Pakistan. This was first time that Balochistan was accorded the status of full fledge province. The Constitution claimed provincial autonomy and provided two lists of powers, Federal and Concurrent. It was promised by the Bhutto Government that Concurrent list would be abolished after ten years giving maximum powers to federating units. But the ethnic dilemma remained unresolved and even these grievances became more problematic during third military regime of Zia-ul-Haq. The four democratically elected governments during 1988-1999 and fourth military period of Pervaiz Mussahraf failed to satisfy the ethnic interests and demands of provincial autonomy. After election 2008, the issue has taken a new turn and demand to divide the most populous province of Punjab is in new swing. The voices of reconfiguration of provincial boundaries are not only being raised by other provinces but southern parts of Punjab are also claiming separate province.

\section{Punjab and Demand for Separate Province}

The Punjab is the largest federating unit with the total population of 73,621,290 million which is almost 55.63 percent (Govt. of Pakistan, 2004, p.1) of the total population of country. The dominant ethnic group is Punjabi with 75.23 percent of the total population of the province while Saraiki are 17.36 percent. According to Census report of 1981, Saraikis were $9.8 \%$ of the total population of Pakistan and $14.9 \%$ of the total population of Punjab province respectively (Ibid). Saraiki is a language of South Punjab which is also spoken in few areas of Sindh and Balochistan. During Colonial era, Saraiki in the Southern parts was considered a dialect of Sindhi. Riasti, Multani, Landha and other dialects were included in Punjabi. The same practice continued till 1981 and it was for the first time during Zia era when Saraiki was listed as a separate language (Ahmed, 1999, pp.25-26). Mostly writers claim that the province of Punjab demographically, can be divided into three zones. The first is Upper and Northern Punjab comprising of Rawalpindi, Jehlum and Chakwal districts. This area is called the Pothohar region. From district of Sialkot to Lahore, certain districts are called Central Punjab which is most populous and influential part of Pakistan. Southern Districts are from the extreme South, bordering Sindh and Balochistan up to Multan and these districts are predominantly Saraiki speaking areas (Shah, 1997, p, 121).

Christopher Shackle was of the opinion that historically different types of languages prevailed in the area of Punjab which he defined as formal standard languages used primarily for writing. These were Sanskrit, Persian, Urdu and English. He claimed that Punjabi had three major groups of spoken dialects, Central Punjabi group, and the Saraiki group of South Western area of the Province below salt range centered in the cities of Multan and Bahawalpur and Hindko group of North West of Punjab. He also mentioned the Pothohari dialect of Rawalpindi area lying between Hindko in Central Punjabi group. This study shows that Shackle considered Saraiki as a dialect of Punjabi (Zingel, 1985, p.317). Grierson, in the linguistic survey of India, writes that language spoken in the West of Jehlum to Bahawalnagar is Southern Landha. Landha is Punjabi word for West and Hindko and Potohari are northern landha. Gankovskhy also considered Saraiki as a dialect of Punjabi. He argued that from 15th century onward, the term Punjabi was used as generic name for Lahori, Multani, Pothwari, Bahawalpuri and other western as well as eastern dialects (Ibid).

Saraiki movement was started in 1960 when first time a move was launched to divide Punjab. Shafqat Tanveer Mirza writes that first time the slogan of local and non-local was raised in Multan in 1962 elections by Sajjad Qureshi, who took on Frooq Sheikh, a Punjabi speaking from Chiniot. Sajjad Qureshi raised the point that Multani is a separate language. The word Saraiki was not vogue in those days (Mirza, 2009, p.19). He also claims (Note 7) that certain bureaucrats in Ayub period, who were very close to him, like Qudrat Ullah Shahab, supported Multani as a separate language (Rehman, 2005, p. 180). According to him, another early protagonist of Saraiki province was senior irrigation Engineer Syed Noor Ali Zaman Haidri. It was in 1971, when Bahawalpur Suba Mahaz movement after the dissolution of One Unit got momentum. Riaz Hashmi formed in 1973, Saraiki Suba Mahaz, the first political organization in Bahawalpur. In 1975, All Pakistan Saraiki Conference was held to promote the cause of Saraiki language. In the same year, the Lawyers of Lahore High Court belonging to Saraiki speaking areas joined this movement and a Saraiki forum was established by Taj Langah, a Lawyer of Multan. This was the first time in Zia regime when Saraiki was listed as a separate language in national Census 1981. On 6th of April, 1984, Saraiki Suba Mahaz was established which latter in April 1989 was changed into Pakistan Saraiki Party (Javaid, 2004, pp. 50-51). After this, the Party entered in an alliance with other parties called PONM (Pakistan oppressed Nations Movement) and these parties have been demanding separate province for Saraiki people. After National Elections 2008, the demand for redrawing the 
provincial boundary of Punjab entered in a new phase and not only the Saraiki nationalist parties but even the major parties like Pakistan People's Party Parliamentarian, Pakistan Muslim League (N), Pakistan Muslim League $(\mathrm{Q})$ and MQM have started to talk about the reconfiguration of this province. The PPPP led Federal government passed a resolution of new province of South Punjab in the National Assembly on May $3^{\text {rd }}, 2012$. Provincial Assembly of Punjab also unanimously passed two separate resolutions in favor of the creation of the province of South Punjab and restoration of the Bahawalpur province. Punjab Assembly also demanded to the Central Government to constitute a national commission for the creation of new provinces.

\section{Saraiki Province versus Bahawalpur Province}

The Punjab is divided in thirty three districts where either Punjabi or Saraiki speaking population is in majority. The table below presents the percentage of dominant and second dominant ethnic community in all districts of Punjab.

The table below analyzes the district wise statistics of dominant and second dominant ethnic group in Punjab province. The table reveals that the Punjabi is the language of majority in twenty five districts in the Province (Note 8). Saraiki is the dominant language in nine districts but Punjabi speakers are also in substantial number in the respective area. As in Multan and Bahawalpur districts, the Punjabis are 21.63 and 28.39 percent respectively. The largest number of Saraiki speakers is in Bhakkar, D.I. Khan, Muzaffar Garh and Rajan Pur.

Though the voices are being raised about division of Punjab but the issue is problematic in its nature. There is a contradiction with in the groups demanding division of province. As the southern districts are predominantly Saraiki but there is a split among Saraiki Nationalists on the issue of Saraiki Province. Some groups are demanding Saraiki province including all Saraiki speaking areas. On the other side, the Bahawalpur province movement is getting strength and their demand is that Rahim Yar Khan to Bahawalnagar including Bahawalpur should be declared a separate province. The protagonists demand that when Bahawalpur State was merged into One Unit in 1955, the government promised to declare it a separate province at the time of dissolution of One Unit. But this promise was not fulfilled and Bahawalpur became a part of Punjab province in federation of Pakistan under the Constitution of 1973 . Their stance is also being supported by political leaders and parties like PML (N).

The protagonists of division of Punjab claim that it would end the domination of Punjab in federal government and strengthen the federation of Pakistan. Their point of view is that creation of new province/provinces would address the economic backwardness and marginalization of southern part of Punjab but an analytical examination reveals that reconfiguration may prove problematic and open new Pandora box of ethnic conflict in Pakistani politics. The issue of the division of Punjab has widened the gulf between PPPP and PML (N). Though the National Government of PPPP has backed the demand of new Saraiki province and passed a resolution in favor of a new province of Southern Punjab but there are certain differences even in the ruling coalition partners on the division of the province. Like Riaz Fatyana of the PML (Q), the coalition partner and Khurram Jahangir Wattoo of PPPP tabled two separate bills in the National Assembly to carve out more provinces out of Punjab.(Dawn, 2012, February 08) The Federal Government has also set up a fourteen member Commission headed by Farhatullah Babar from PPPP to finalize the details. On the other side, PML (N), the ruling Party in Punjab has demanded the creation of two new provinces, Southern Punjab and Bahawalpur province (Note 9). They have even criticized the formation of Commission and the issue has become even more problematic. The demand to divide southern Punjab and inclusion of certain districts in Saraiki province has also created uproar in the upper districts of Punjab. The evidence is the demand for Thal province in Punjab Provincial Assembly on August 10, 2011 by Ali Haider Noor Niazi. He agitated on the inclusion of Mianwali, his native town, in Saraiki province by proponents of Saraiki province movement (Dawn, 2011).

The division of Punjab would also affect the other provinces where ethnic conflict already persists and encourage certain ethnic communities to demand the same right for themselves. For example in Khaber Pakhtoonkhawa, the Hindko speaking community has started agitation for separate province while Pashtoons under the banner of ANP are not ready to acknowledge this demand (Roofi, 2011, pp. 588-593). Ethnic conflict in Sindh particularly in Karachi and Hyderabad areas is already problematic. The Sindhi nationalist parties have started protests against the presentation of $20^{\text {th }}$ Constitutional amendment bill in the National Assembly by MQM for the creation of new provinces. Their belief is that creation of new provinces will prove detrimental for the interests of Sindhi speaking community because Mohajirs may demand separate province in future for themselves (Note 10). There is a sharp cleavage between Baloch and Pashtoons in Balochistan and now Hazara community has started raising voices in the province. If the demand of separate Bahawalpur province is materialized, it may give birth to new demand by other formerly princely states like Khairpur, Kalat, Dir, Chitral 
etc. Even after division, the situation may aggravate in certain districts of new province in future where Punjabi speakers are in sufficient numbers, for example in Bahawalnagr, Layyah and Multan (Note 11).

Table 1. Largest and second largest ethnic group in all districts of Punjab

\begin{tabular}{|c|c|c|c|c|}
\hline District Name & D.E.G. & $\%$ of D.E.G & $2^{\text {nd }}$ E.G. & $\% 2$ nd D.E.G \\
\hline Atttock & Punjabi & 87.14 & Pashto & 8.31 \\
\hline Bahawalpur & Saraiki & 65.15 & Punjabi & 28.39 \\
\hline Bahawal Nagar & Punjabi & 94.61 & Urdu & 3.74 \\
\hline Bhakkar & Saraiki & 72.99 & Punjabi & 17.45 \\
\hline Chakwal & Punjabi & 97.69 & Pashto & 1.15 \\
\hline D.G.Khan & Saraiki & 80.25 & Balochi & 14.33 \\
\hline Faisal Abad & Punjabi & 97.47 & Urdu & 1.17 \\
\hline Gujrat & Punjabi & 98.04 & Urdu & 1.06 \\
\hline Gujranwala & Punjabi & 97.03 & Urdu & 1.88 \\
\hline Hafiz Abad & Punjabi & 98.66 & Urdu & 0.9 \\
\hline Jehlum & Punjabi & 96.58 & Urdu & 1.93 \\
\hline Jhang & Punjabi & 95.85 & Urdu & 3.31 \\
\hline Kasur & Punjabi & 88 & Urdu & 6.23 \\
\hline Khanewal & Punjabi & 81.20 & Urdu & 7.78 \\
\hline Khushab & Punjabi & 96.8 & Urdu & 1.48 \\
\hline Lahore & Punjabi & 86.18 & Urdu & 10.19 \\
\hline Layyah & Saraiki & 62.25 & Punjabi & 32.55 \\
\hline Lodhran & Saraiki & 69.01 & Punjabi & 18.06 \\
\hline Mandi Bahuddin & Punjabi & 96.97 & Urdu & 2.45 \\
\hline Mianwali & Punjabi & 74.17 & Saraiki & 1.48 \\
\hline Multan & Saraiki & 60.67 & Punjabi & 21.63 \\
\hline Muzzafar Grah & Saraiki & 86.83 & Punjabi & 7.47 \\
\hline Narowal & Punjabi & 98.02 & Urdu & 1.24 \\
\hline Okara & Punjabi & 95.71 & Urdu & 3.51 \\
\hline Pak Patan & Punjabi & 95.87 & Urdu & 3.67 \\
\hline Rahim Yar Khan & Saraiki & 62.62 & Punjabi & 27.31 \\
\hline Rajan Pur & Saraiki & 75.72 & Balochi & 17.1 \\
\hline Rawal Pindi & Punjabi & 83.89 & Urdu & 7.46 \\
\hline Sahi Wal & Punjabi & 98.07 & Urdu & 1.42 \\
\hline Sargodha & Punjabi & 93.28 & Urdu & 5.84 \\
\hline Sheikopura & Punjabi & 98.1 & Urdu & 0.95 \\
\hline Sial Kot & Punjabi & 97.11 & Urdu & 1.49 \\
\hline Toba Tek Singh & Punjabi & 98.59 & Urdu & 0.78 \\
\hline Vehari & Punjabi & 82.85 & Saraiki & 11.35 \\
\hline
\end{tabular}

Source: Roofi, Yasmin. Ethnic Nationalism and Political Development: A Case Study of Pakistan. (2009). Un published Ph. D. Dissertation Submitted at Department of Political Science and International Affairs, B.Z. University, Multan, Pakistan. 


\section{Conclusion}

The issue of reconfiguration of provincial boundaries particularly Punjab is not new in Pakistan. The demand has been raised by the smaller provinces in the past to divide the province but now intra provincial struggle has also joined the move. There is no harm to reconfigure the province but there are certain complexities involved in division of Punjab. The division, with in the given political structure, will affect not only Punjab but it would leave an impact on rest of the provinces and ethnic dilemma may aggravate in Pakistan. So there is a need to create consensus and devise a concrete strategy while keeping all pros and cons in mind by political elites before the final decision.

\section{References}

Ahmed, F. (1999). Ethnicity, State and National Integration. Pakistan Perspectives, 4(2). Karachi: Pakistan Study Centre.

Amin, T. (1988). Ethno National Movements of Pakistan: Domestic and International Factor. Islamabad: Institute of Policy Studies.

Asghar, R. (2012, February 8) furry in PPP Over Ally's Provinces Bill. Retrieved from.http://dawn.com/2012/02/08/fury-in-ppp-over-allys-provinces-bill/

Cohen, S. (2000). The Pakistan Army (3rd ed.). Karachi: Oxford University Press.

Hussain, A. (1966). Mian Fazl-i-Hussain: A Political Biography. London.

Jalal, A. (1985). The Sole Spokes Man; Jinnah, the Muslim League and Demand for Pakistan. Cambridge: Cambridge University Press.

Javaid, U. (2004). Saraiki Political Movement; Its impact in South Punjab. Journal of Research Humanities, 40(2). Lahore: University of Punjab.

Mahmood, A. (2011, August 12). Rumpus in Punjab PA Over Saraiki Province. Retrieved from $\mathrm{http} / / /$ dawn.com/2011/08/12/rumpus-in-punjab-pa-over-seraiki-province/

Malik, I. H. (1997). State and Civil Society in Pakistan; Politics of Authority, Ideology, and Ethnicity. Baring stoke: Macmillan.

Mirza, S. T. (2009, May 24). The Origin and Politics of Saraiki Movement. Lahore: Daily Dawn.

Population Census Organization. (2004). Population of Administrative Units. Islamabad: Government of Pakistan.

Rehman, T. (2003). Language and Politics in Pakistan (3rd ed.). Karachi: Oxford University Press.

Roofi, Y., \& Ayyaz, M. (2011). Renaming of NWFP and Hazara Ethnicity; A New Course of Ethnic Conflict in Pakistan. European Journal of Social Sciences, 19(4). Retrieved from http://www.eurojournals.com/EJSS_19_4_14.pdf.

Salamat, Z. (1997). The Punjab in 1920s; A Case Study of Muslims. Karachi: Royal Book Company.

Shah, M. A. (1997). The Foreign Policy of Pakistan; Ethnic Impacts on Diplomacy (1971-1994). London: I.B. Tauris and Company.

Talbot, I. (1990). Provincial Politics and the Pakistan Movement; the Growth of the Muslim League in North-West and North-East India 1937-47. Karachi: Oxford University Press.

Waseem, M. (1994). Politics and the State in Pakistan. Islamabad: National Institute of Historical and Cultural Research.

Zingle, W. P., \& Stephanie, A. L. (1985). Pakistan in the 80s. Lahore: Vanguards Books.

\section{Notes}

Note 1. According to Dr. Pritam Singh, Punjab was not the last region annexed by the British but Jhansi, Nagpur and Hyderabad were annexed in 1853 and Awadh was annexed in1856. For details, Singh, Pritam. (2008). Federalism, Nationalism and Development: India and Punjab Economy. London: Routledge. P.183.

Note 2. A commission was sent by the British government in 1928 to India to negotiate with political leaders and formulate proposals about future of Indian Sub-Continent. 
Note 3. Even in 1942, the Sikander Hayat was trying to probe the possibility of a deal with the All India National Congress.

Note 4. There were certain elements in these provinces during independence movement who were in favor of separate independent state for their region, for example Red Shirt movement in NWFP, G.M. Syed in Sindh, and Huusain Shaheed Suhrawardy in Bengal etc.

Note 5. After passing Objective Resolution by the first Constituent Assembly, Basic Principles Committee was appointed to draft proposals regarding the future constitution of Pakistan. The Committee was further divided into three sub committees, Sub Committee on Franchise, Sub Committee on Judiciary and Sub Committee on Distribution of Powers among Central Government and its federating units.

Note 6. The Punjabis were in majority in army even before independence because of recruitment policy of British Government in India. The British were of the view that Punjabis and Pashtoons are the Martial races so the Punjabis were 77 percent in pre partition Army. Though efforts were made to increase the representation of other ethnic communities particularly East Pakistanis after independence but it did not affect the real situation.

Note 7. Tariq Rehman in his book Language and Politics in Pakistan also shares the same point.

Note 8. The spoken dialect of Punjabi in northern districts of Rawalpindi, Jehlum and Chakwal is Pothohari.

Note 9. PML (N) proposed the formation of two more provinces, Federally Administered Tribal Area (FATA) and Hazara in Khyber Pakhtoonkhawa.

Note 10. Dr. Qadir Magsi of Sindh Taraqqi Pasand Party, Syed Jalal Mehmood Shah, Ayaz Latif Plejo of Awami Tehrik and many other nationalist leaders condemned the MQM move to table $20^{\text {th }}$ Constitutional Amendment Bill in the Assembly to redraw more provinces in Punjab and Khyber Pakhtoonkhawa. Their point of view is that present Parliament is not authorized to reconfigure the national or provincial boundary and new social contract is required in this regard.

Note 11. The population in Bahawalnagr is predominantly Punjabi While in Layyah and Multan their numerical strength is 32.55 and 21.63 percent respectively.

\section{Acronyms}

Abbreviation

ANP

$\mathrm{BPC}$

MQM

PML (N)

PML (Q)

PPPP

\author{
Political Party \\ AAwami National Party \\ Basic Principles Committee \\ Muttahida Qaumi Movement \\ Pakistan Muslim League (Nawaz Group) \\ Pakistan Muslim League (Quaid-e-Azam Group) \\ Pakistan People's Party Parliamentarians
}

